\title{
Success Stories: IVLP beneficiaries in Bivoltine Double Hybrid Silkworm Rearing
}

\author{
Dr. P. M. M Reddy ${ }^{1}$, M. Ramesh ${ }^{2}$ \\ ${ }^{1}$ Sci-C, Central Silk Board, Madanapalli, Chittoor, A.P, India \\ ${ }^{2}$ Sci-D, SSPC, Central Silk Board, Madanapalli, Chittoor, A.P, Inda
}

\begin{abstract}
The Institute Village Linkage Programme (IVLP) implementation of biovltine double hybrids silkworm rearing and technology transfer, considering the needs of the end users/beneficiaries in Madanapalli cluster. Sericulture is one of the most important rural industries practiced since several decades. It has certain inherent advantages of bivoltine double hybrids rearing in Madanapalli area through. "INSTITUTE VILLAGE LINKAGE PROGRAMME” (IVLP) Central Silk Board, XII Plan for implementation of Bivoltine Double Hybrids which has resulted in improvement in the productivity levels of beneficiary farmers.
\end{abstract}

Keywords: IVLP, Bivoltine double hybrids, Silkworm Rearing, Mulberry variety

\section{Introduction}

The programme has been introduced at central silk board and in association with State DOS level to educate sericulturists, still a wide gap exists between the recommended technology and actual adoption by Seri culturists. To plan a suitable intervention strategy, to bridge this gap, it is necessary to understand the present knowledge and adoption level for improved technologies, so also existing mulberry leaf yield and silk cocoon production level. Therefore, present study was conducted to know the extent of adoption of improved practices at farmer's level in selected areas of Madanapalli B- Kothakota, PTM, Thambalapalli, Mulkalachruvu, coveringfive locations with purpose of finding whether or not by adopting the improved sericultural technologies are transferred meticulously and adopted sincerely. A gain to the extent an average of 55$60 \mathrm{Kgs}$ to $65-70 \mathrm{Kgs}$ increases in cocoon yield over the adaptation of new technologies. The details of the sericulture technologies demonstrated like package of practices, to maintain the soil structure, nursery technics, Plantation spacing, application of manure, disease and pest management, rearing management and cleaning of rearing houses (disinfection)etc; and their cumulative impact are discussed.

Farmers Success story of Mr. B. Shivaiah,Yenganagaripalli , Mulakalcharu, Mandal He has reared bivoltine double hybrid silkworm, separately well maintained suitable ,V1Mulberry Garden and drip irrigation 3.5acrs and separate rearing house for the capacity of 350dfls per crop earlier he reared crass breed ( $\mathrm{C} B$ ) race and he produced 7580kgs@rate of Rs.320/kg know he shifted to double hybrid rearing Madanapalli source he reared first crop 350dfls cocoon yield total $265 \mathrm{kgs}$ per $100 \mathrm{dfls}$ yield $75 \mathrm{kgs}$ and he get
@ of Rs. 362/kg the total income present crop is Rs. 95930/ (Ninty five thousand nine hundred thirty only) he reared per year minimum 10crops and 8-10 years experiences in mulberry sericulture he told only sericulture is the best option in present ecological condition. He is very much willing to Bivoltine double hybrid rearing, Sericulture is only one of my occupation and also look after my family by increasing annual income through mulberry sericulture.

Mr. Chandramohan Reddy Kukalapalli Village BKothakotaMandal $\mathrm{He}$ is sericulture graduate (M.Sc, in sericulture) he maintained 2.5 acres of Mulberry garden variety $\mathrm{V}_{1}$ and well systematic technologies adopted paired raw system divided two plates, separate rearing house adopted shot system per crop 200dfls per year 10-12crops reared (every month crop 200dfls) cocoon yield per 100dfls $75-80 \mathrm{kgs}$ total each batch $150-160 \mathrm{kgs}$ of cocoons produced and an average market price per kg 300-350 rupees 4500050000 thousand per month income he opted sericulture is the best option in present ecological condition. He is very much interested inBivoltine double hybrid rearing and new technologies adopted. Sericulture is only one of my occupation and also look after my family by increasing annual income through mulberry sericulture.

\section{Outcome Expected}

After successful implementation of the IVLP project, the covered farmers shall be self-reliant in respect of sericulture technologies, able to take up 10-12 rearing's (farmers are dividing the mulberry garden in to two batches, every month crop/rearing) per annum and enhance their income for better livelihood. It will also have positive impact on the neighboring farmers and the entire area shall be benefitted. 


\section{International Journal of Science and Research (IJSR) \\ ISSN (Online): 2319-7064}

Index Copernicus Value (2013): 6.14 | Impact Factor (2015): 6.391

Photographs
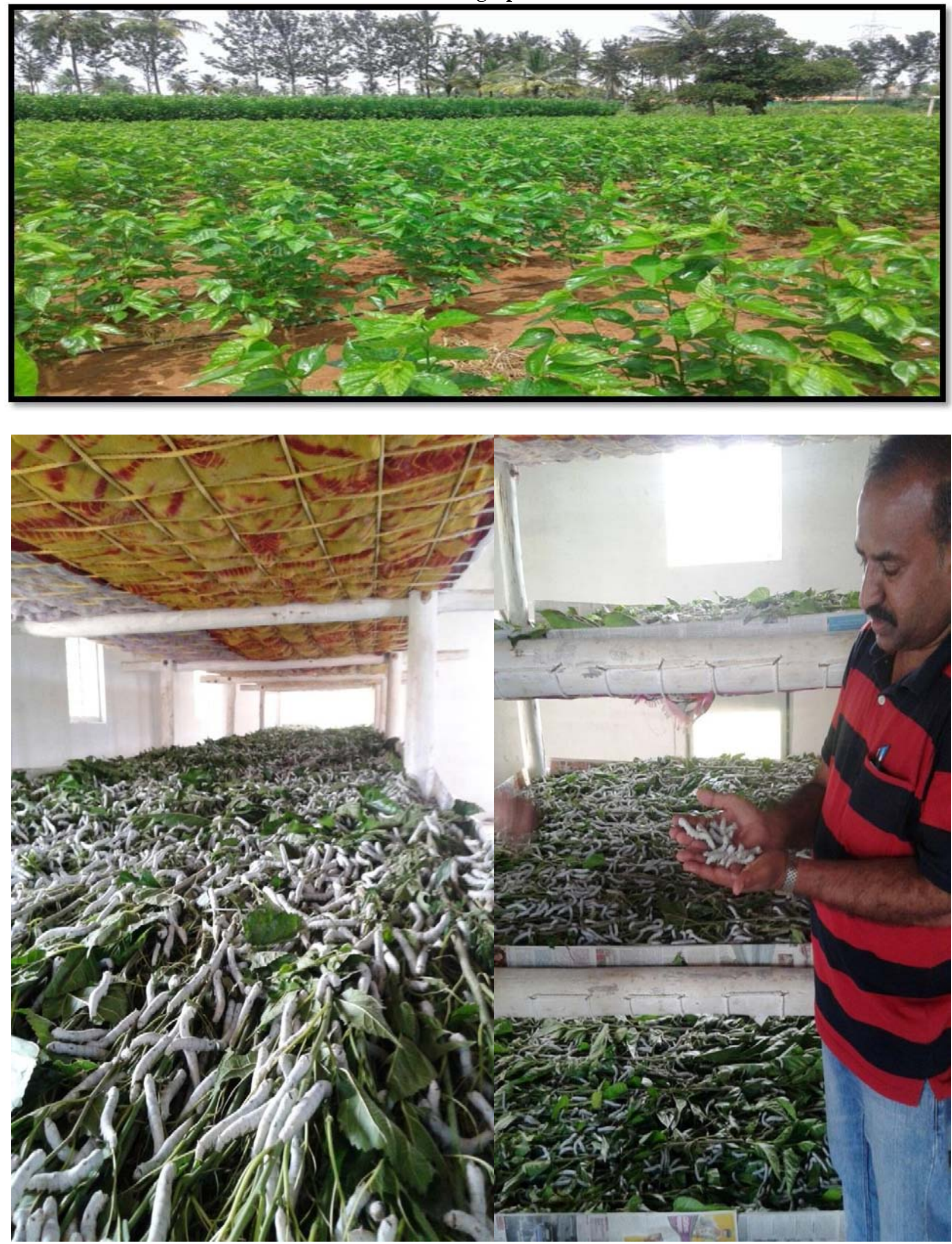

Volume 5 Issue 4, April 2016

www.ijsr.net 
International Journal of Science and Research (IJSR)

ISSN (Online): 2319-7064

Index Copernicus Value (2013): 6.14 | Impact Factor (2015): 6.391
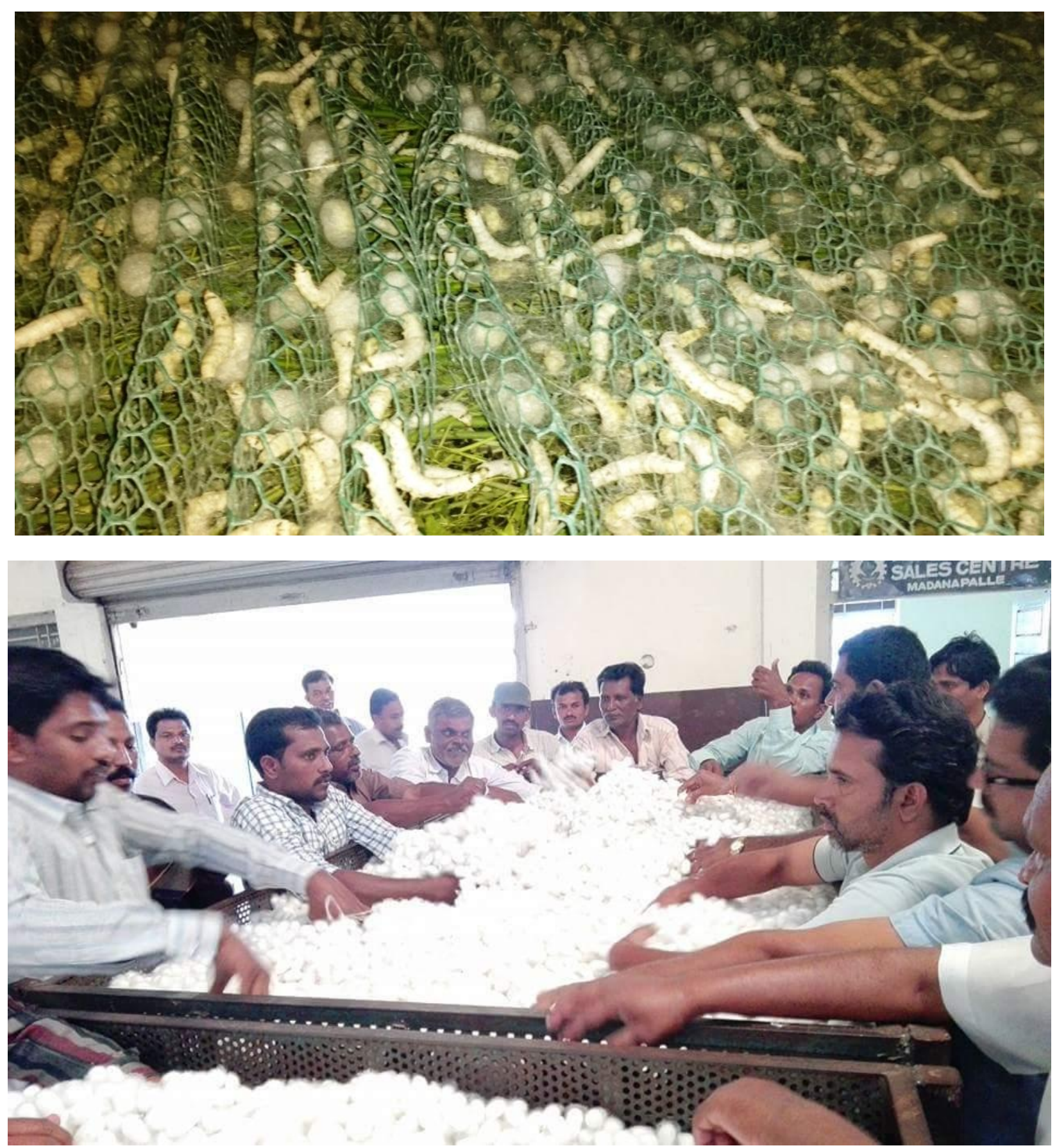

Volume 5 Issue 4, April 2016 www.ijsr.net 
International Journal of Science and Research (IJSR)

ISSN (Online): 2319-7064

Index Copernicus Value (2013): 6.14 | Impact Factor (2015): 6.391

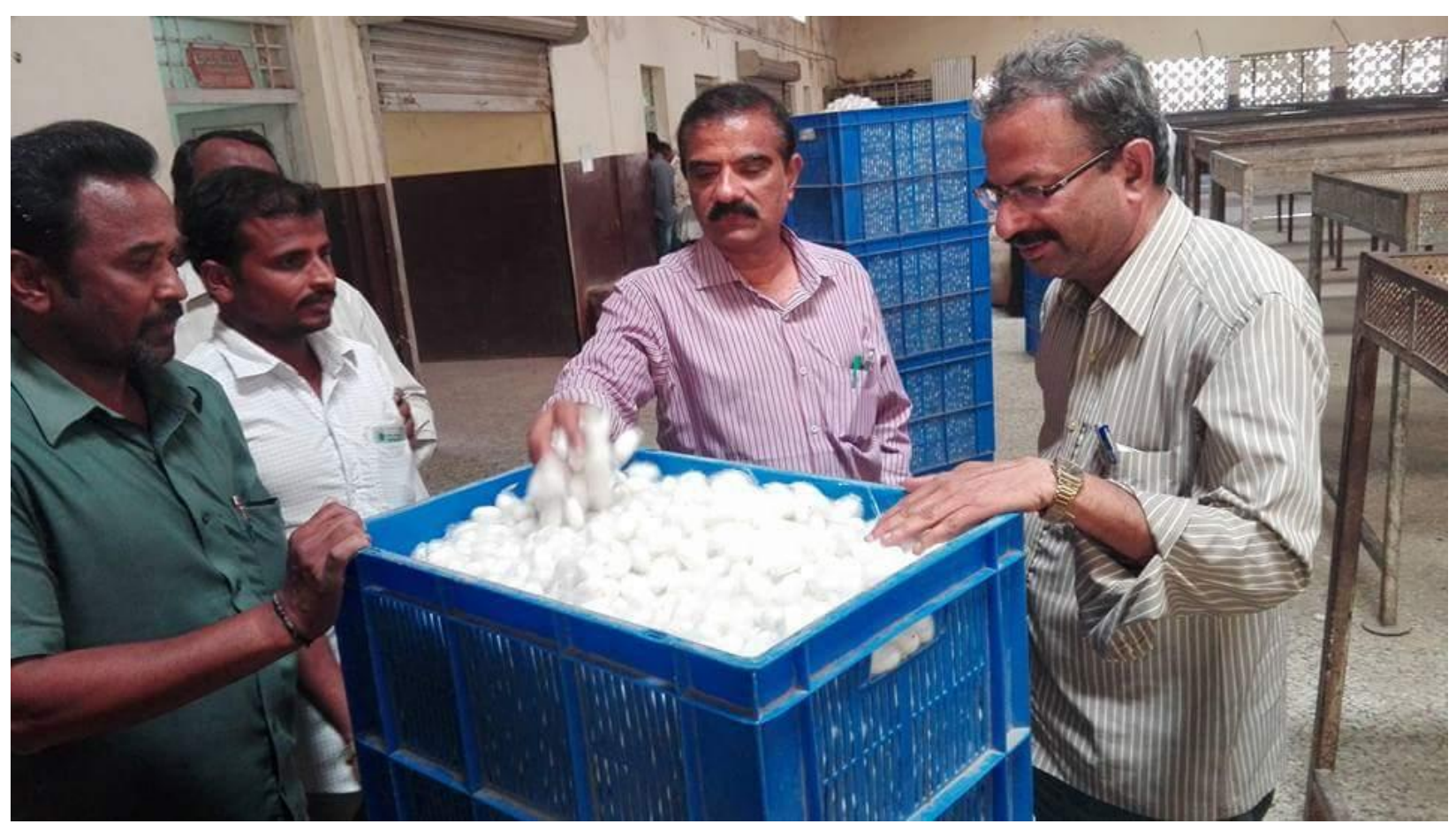

Volume 5 Issue 4, April 2016 www.ijsr.net 